\title{
The Urgency of the State Budget Revision: Political and Legal Perspectives
}

\section{Erawati}

Directorate General of Budget, Ministry of Finance. E-mail: erawati3@gmail.com

\begin{tabular}{|c|c|}
\hline ARTICLE INFO & ABSTRACT \\
\hline $\begin{array}{l}\text { Keywords: } \\
\text { political and legal } \\
\text { perspectives; revision; state } \\
\text { budget. } \\
\text { How to cite: } \\
\text { Erawati. (2019). The } \\
\text { Urgency of the State } \\
\text { Budget Revision: Political } \\
\text { and Legal Perspectives. } \\
\text { MEDIA HUKUM, +62 } \\
\text { 274 387656 (Ext. 220) } \\
\text { Article History: } \\
\text { Received: } 28-2-2019 \\
\text { Reviewed: 26-8-2019 } \\
\text { Revised: 23-12-2019 } \\
\text { Accepted: 23-12-2019 }\end{array}$ & $\begin{array}{l}\text { This article aims to discuss the urgency of state budget revision and } \\
\text { if the conditions, as stated in the MD3 Act are met, and the } \\
\text { government takes steps not to propose an amended state budget with } \\
\text { specific considerations, whether this government's action is } \\
\text { considered to violate the laws or regulations or not. This is a } \\
\text { normative legal research that uses statute approach. The result of the } \\
\text { study shows that the urgency of state budget revision is to ensure the } \\
\text { soundness of the implementation of the current year's state budget by } \\
\text { adjusting the amount of state revenue, state expenditure, budget } \\
\text { deficits, and budget financing to more realistic levels that allow the } \\
\text { achievement of specified development targets. In the light of the } \\
\text { Presidential system in Indonesia, the government's decision not to } \\
\text { propose a revision of the state budget if the criteria to revise it, as } \\
\text { stipulated in the State Finance Law and MD3 Law are fulfilled, } \\
\text { theoretically is not a violation of the current laws and regulations. } \\
\text { The choice to submit or not submit a revision of the state budget, } \\
\text { after going through careful consideration by the government, is } \\
\text { aimed at maintaining its credibility since the existence of a revision } \\
\text { implies that the government is unable to undertake precise budget } \\
\text { planning. }\end{array}$ \\
\hline
\end{tabular}

DOI: 10.18196/jmh.20190132

Copyright (๐ 2019 MEDIA HUKUM. All rights reserved.

\section{Introduction}

State Budget (APBN) is the annual financial plan of the government to achieve the state's objectives. ${ }^{1}$ The national budget is an important policy instrument for achieving the set development goals. As a policy tool, the credibility and strength of the APBN depend on the accuracy of each number, and the policy behind them which describes the quality of the economic, political and legal processes used for its preparation and

\footnotetext{
1 Direktorat Penyusunan APBN, Ditjen Anggaran, Kementerian Keuangan Republik Indonesia. (2014). Dasar-Dasar Praktek Penyusunan APBN di Indonesia. Jakarta: Direktorat Penyusunan APBN, Ditjen Anggaran, Kementerian Keuangan Republik Indonesia, p. 7.
} 
determination, as well as compliance with the implementation of the figures resulting from agreement with the APBN itself.

Before the reform era, Indonesia only produced one state budget every year. But during the reform era, there have been two budgets each year, namely the APBN and the amended APBN. Experts differ in their views of the amended APBN. Some parties argue that the revised state budget shows the government's inability to plan the budget precisely. They consider that a revised state budget should only be produced when the economic conditions experience extraordinary changes which are beyond the control of the government, or force majeure. The culture of revising the state budget in the past few years had triggered the members of the $\mathrm{DPR}^{2}$ as a transactional venue for corruption. The division and cooperation of the projects often happened during the discussions about the revised state budget. It is because the reviews about the revised state budget usually take place so quickly that they escape scrutiny by the public and media. Many cases of corruption involving the legislature and executive stem from discussions on a revised state budget, such as the Regional Infrastructure Adjustment Fund (DPID) case, the construction project for the Hambalang National Sports Training and Education Center, the Wisma Athlete case, the case of the procurement of the Holy Qur'an at the Ministry of Religion, etc. ${ }^{3}$

During the era of President Susilo Bambang Yudhoyono (SBY), the budget in the amended APBN was usually always higher than in the APBN. Even the expenditure budget was raised, though the target for state revenue was lowered. For example, the 2013 APBN total budget was IDR 1,529.7 trillion, while state expenditure was IDR 1,683 trillion. Then in the revised state budget, the state's revenue was reduced to IDR 1,488.32 trillion, but the state budget was raised to IDR 1,722.03 trillion. The impact of this policy was that the state budget's deficit grew, but from the markets' perception, the increase in spending was actually seen as a positive thing. Regardless of the reason why the government increased spending, the markets thought that the move would cause an expansion in economic growth so that the wheels of the economy spun faster. ${ }^{4}$

During the administration of President Joko Widodo, there has been a change in the pattern of the revised state budget. During the previous president's time in office, the budget tended to be increased in the revised state budget, in the era of President Joko Widodo's administration, the budget has actually been lowered. For example in the 2015 State Budget the state revenue was set at IDR 1,739.6 trillion, while the state expenditure was IDR 2,039, 5 trillion. Then in the 2015 Revised State Budget, state revenues were increased to IDR 1,761.6 trillion, while state expenditures were reduced to IDR 1,984.1 trillion. That was caused by the slowdown of the global and domestic economies. The Japanese and European economies were still in decline, and although though the US economy was in recovery, it was not substantial. The Chinese economy was in a more stable condition, but there was still a high risk of it weakening. Domestically, falling commodity prices, especially coal, had made many mining companies lost money and even go out of business. The impact of this was that state

\footnotetext{
2 The House of Representative of Republic of Indonesia

${ }^{3}$ Marta, M. F. (2016), “APBN Perubahan atau APBN Pengurangan?” Kompas.com, https://money.kompas.com/read/2016/06/03/081844826/strategi.anggaran.jokowi.apbn.perubahan.at au.apbn.pengurangan.?page=all, [Accessed September 3, 2019.

4 Kementerian Keuangan Republik Indonesia. (2016). Nota keuangan dan Undang-Undang Republik Indonesia nomor 36 tahun 2004 tentang Anggaran Pendapatan dan Belanja Negara Tahun Anggaran 2016. Jakarta: Kementerian Keuangan Republik Indonesia, p. I-1 -. I-5.
} 
revenues, especially from taxes, had fallen considerably, and falling oil prices have made the revenue from oil and gas fall dramatically. Budget revisions, in form of budget cuts, from an economic point of view are like the two sides of a coin. On one hand, they are ways to reduce the state budget's deficit, but from the point of view of the markets and investors there are something that should be avoided by the government, since it can disrupt the markets and investors, causing them to reduce their activities, which have an impact on the economic downturn. Budget revisions, in the form of reducing the expenditure ceiling in the amended APBN, will also make the government's credibility fall, because it is deemed to be incompetent in designing and executing the budget. Trust is a fundamental and sensitive issue, considering that the government must be able to maintain the markets' and investors' confidence.

The basis for the amended APBN is the existence of Article 23 of the 1945 Constitution which mandates that the APBN must be determined by law, after going through discussions and mutual agreement with the DPR, and taking into account the opinion of the DPD. In the course of the stipulated APBN law, it is possible to make changes if the state by either experiencing an emergency condition, or the conditions stipulated in Article 27 of the Law on State Finance is met. The criteria for the urgency of the amended APBN is sharpened in Article 183 of the Law on MPR ${ }^{5}, \mathrm{DPR}, \mathrm{DPD}^{6}$ and $\mathrm{DPRD}^{7}$ (MD3 Law), by setting a certain permitted percentage of changes to the macroeconomic assumptions, and changes to the budget's posture. However, these additional criteria create their problems since such measures have the potential always to be fulfilled given the macro assumptions are highly depend on the condition of the world's economy, so that it binds the government to carry out APBN amendments. It leaves the government with a dilemma. On one hand the government is bound by the MD3 Law, but on the other hand the government wants to maintain its credibility, bearing in mind the existence of the revised state budget shows the government's inability to make precise budget planning.

This article aims to find out that if the conditions as stated in the MD3 Act are met, and the government takes steps not to propose an amended state budget with specific considerations, whether this government's action is considered to violate the laws or regulations or not.

\section{Method}

This research uses normative research methods. According to Peter Mahmud Marzuki normative research is the process of finding a rule, principle, and legal doctrine, to produce new arguments, theories, or concepts as a prescription in solving problems faced. ${ }^{8}$ Rules, principles, and legal doctrines from various literacy sources are used to find out whether if the conditions as stated in the MD3 Act are met, and the government takes steps not to propose an amended state budget with specific considerations, the government's action is considered to violate the laws or regulations or not.

\footnotetext{
5 People Consultative Assembly of Republic of Indonesia.

${ }^{6}$ Regional Representative Council of Republic of Indonesia.

7 Regional House of Representative of Republic of Indonesia.

8 Marzuki, P.M. (2005). Penelitian Hukum. Jakarta: Kencana Prenada Media Group, p. 3.
} 


\section{Analysis and Results}

\subsection{Indonesia's Budgeting System}

The implementation of governmental functions in various fields causes the rights and obligations of the state to be valued in monetary terms. It needs to be managed using some forms of state financial management system. The authority over the management of state finances is stated in Chapter II of Law Number 17 Year 2003 concerning State Finances. Article 6 paragraph (1) states that the President, as the Head of the Government, holds power to manage the state's finances as part of his/her governmental powers. In the explanation of the article, it states that the power includes a general authority and an exclusive authority. This general authority includes setting the direction, public policies, strategies, and priorities for managing the state budget, including determining the implementation guidelines and accountability for the state's revenue and expenditure budgets, setting guidelines for preparing the line ministries/agencies work plans, determining salaries and benefits, and instructions for managing state revenues. The exclusive authority includes decisions on technical policies relating to the management of the state's revenue and expenditure budgets, including decisions by the Cabinet for the management of the state's revenue and expenditure budgets, the decision about the balance fund, and the write-off of state assets and receivables. ${ }^{9}$

The state's finance law defines the budget as a tool to provide accountability, management, and economic policy. Indonesia's income and expenditure budgets are outlined in the state budget every year and must obtain approval from the DPR. As a policy tool, the credibility and strength of the APBN highly depend on the accuracy of each number, and the policy behind each number that describes the quality of the economic, political and legal processes used in its preparation and determination, as well as compliance with the implementation of the figures resulting from the agreement about the APBN itself. The APBN is also a representation of the government's competence in developing sound budgetary planning and its ability to anticipate the challenges of managing state finances due to global economic developments. In accordance with the mandate of the 1945 Constitution, the APBN must be realized in the form of a law, after going through discussions and mutual agreement with the DPR, and taking into account the opinion of the DPD. Arifin P. Soeria Atmadja illustrated the relationship between the nature of the law and the figures in the APBN as follows: "APBN figures without the legal nature of the APBN law is like a soulless body, while the legal nature of the APBN law without numbers is like a physically incomplete body." The APBN act, according to Arifin P. Soeria Atmadja, is not a material law because it only binds the government and does not bind the general public. Besides that, the state budget law has elements of periodicity and continuity that are not contained in other laws. ${ }^{10}$

9 Direktorat Penyusunan APBN, Ditjen Anggaran, Kementerian Keuangan Republik Indonesia. (2014). Dasar-Dasar Praktek Penyusunan APBN di Indonesia. Jakarta: Direktorat Penyusunan APBN, Ditjen Anggaran, Kementerian Keuangan Republik Indonesia, p. 2-3.

10 Atmadja, A. P. S. (1978). “Sifat Hukum Dari Undang-Undang Anggaran Pendapatan dan Belanja Negara", Jurnal Hukum dan Pembangunan, 8(3):. 
Dian Puji N. Simatupang distinguishes the character and legal nature of the APBN Law and other laws as follows: ${ }^{11}$

\begin{tabular}{|c|c|c|c|}
\hline No & $\begin{array}{c}\text { Distinguishing Character } \\
\text { And Character }\end{array}$ & State Budget Law & Non-APBN Law \\
\hline 1 & $\begin{array}{l}\text { The legal basis in the } 1945 \\
\text { Constitution }\end{array}$ & Article 23 & Article 20 \\
\hline 2 & $\begin{array}{l}\text { Functions carried out by the } \\
\text { DPR }\end{array}$ & Budget function (budget) & Legislation function \\
\hline 3 & Rights owned by the DPR & Budget rights & Legislative rights \\
\hline 4 & $\begin{array}{l}\text { The party that initiated the } \\
\text { law }\end{array}$ & Government & Government and parliament \\
\hline 5 & Validity period & One year & $\begin{array}{l}\text { Not determined as long as not } \\
\text { revoked }\end{array}$ \\
\hline 6 & Binding power & Government & Binding everyone \\
\hline 7 & Content material & $\begin{array}{l}\text { Determination of the state } \\
\text { budget }\end{array}$ & Settings in certain fields \\
\hline 8 & Submission mechanism & $\begin{array}{l}\text { The President delivered directly } \\
\text { in the DPR plenary session } \\
\text { accompanied by a financial } \\
\text { memorandum }\end{array}$ & $\begin{array}{l}\text { The President appoints the } \\
\text { minister to convey the } \\
\text { President's mandate in the } \\
\text { DPR session }\end{array}$ \\
\hline 9 & $\begin{array}{l}\text { Possible formation in Perpu } \\
\text { (Government Regulation in } \\
\text { Lieu of Law) }\end{array}$ & Not possible & Possible \\
\hline 10 & Mechanism of change & $\begin{array}{l}\text { By submitting the revised / } \\
\text { additional state budget bill } \\
\text { before the end of the budget } \\
\text { period }\end{array}$ & $\begin{array}{l}\text { By submitting the amended } \\
\text { bill when needed }\end{array}$ \\
\hline 11 & $\begin{array}{l}\text { Constitutional settlement if } \\
\text { the DPR rejects the act }\end{array}$ & $\begin{array}{l}\text { Use the state budget from last } \\
\text { year }\end{array}$ & $\begin{array}{l}\text { The bill cannot be submitted } \\
\text { during the trial period }\end{array}$ \\
\hline 12 & $\begin{array}{l}\text { Possibility of the DPR } \\
\text { submitted the initiative right }\end{array}$ & Not possible & Very possible \\
\hline 13 & $\begin{array}{l}\text { Legal action by the } \\
\text { government }\end{array}$ & Government deeds & The formation of legislation \\
\hline 14 & $\begin{array}{l}\text { Form of implementing } \\
\text { regulations }\end{array}$ & Presidential decree & Government regulations \\
\hline 15 & $\begin{array}{l}\text { Possible violation of citizens' } \\
\text { constitutional rights }\end{array}$ & Not possible & Possible \\
\hline
\end{tabular}

\subsection{Development of Indonesia's Budgeting System}

The Indonesian budgeting system initially followed the traditional budgeting system, which was in use until 1970/1971 for the development budget, and 1973/1974 for the routine budget. The traditional budgeting system emphasizes the aspects of the budget's execution and oversight. In the execution stage, each department/institution's rights are strongly emphasized, following the objectives and following the applicable regulations and procedures. In the supervision stage, priority is given to the validity of the transaction's evidence and the reasonableness of the financial statements. ${ }^{12}$

The development of Indonesian budgeting led to the creation of the Performance Budget System (PBS). This system was first introduced in 1970/1971 for the

11 Dian Puji N. Simatupang, D. P. N. (2011). Paradoks Rasionalitas Perluasan Ruang Lingkup Keuangan Negara dan Implikasinya terhadap Kinerja Keuangan Pemerintah. Jakarta: Badan Penerbit FH UI, hlm. 145-147.

12 Pusat Kajian Anggaran DPR RI, Sistem Penganggaran. Berkas.dpr.go.id, https://berkas.dpr.go.id/puskajianggaran/peristiwa/file/peristiwa-4.pdf, [Accessed September 5, 2019]. 
development budget. The budget was determined based on development targets that had to be achieved, utilizing development projects which were administratively listed in the Project Entry List (Daftar Isian Proyek/DIP). The DIP contained a concrete plan and estimated costs that must be approved by the Minister of Finance and Bappenas ${ }^{13}$. It also included other matters such as the person in charge of the project, the project's name, its location, start time and estimated finish date. The application of the PBS with the routine budget started in 1973/1974. In the routine budget, the Activity Entry List (Daftar Isian Kegiatan/DIK) was used as the basis for authorizing the departments/ institutions to implement the routine expenditure budget, which also must obtain approval from the Minister of Finance. The DIK contained information about the line ministry/agency in charge of the budget, its activities, the implementing offices, the units of activity results and units of activity volume. By implementing the DIP and DIK since 1973/1974, Indonesia officially adopted the PBS. This system puts more emphasis on the budget's management aspects which include consideration of the economic and financial issues, the budget's execution, and its physical achievements. In this system, the functions of each department institution are also considered, as well as the grouping of the activities (work performance units). ${ }^{14}$

To improve Indonesia's budgeting system, changes had been made through Law 17 of 2003 concerning State Finance (State Finance Law). The State Finance Law brings some significant changes to the budgeting system. One of them is integrated budgeting, where there is no longer a separation between the routine budget and the development budget. It is crucial as it avoids duplication, and the build-up and deviation of the resources allocated. Another meaningful change is the implementation of a mediumterm budgeting approach to reduce uncertainty about the provision of funds in the future, and to encourage line ministries/agencies to analyze matters to determine whether it is necessary to make changes to policies deemed to be ineffective, so that new policies can be accommodated. Lastly, the State Finance Law introduces performance-based budgeting. It incorporates an accountability performance system into the budgeting system by using a document called a Ministry/Agency Work Plan and Budget (RKAK/L). The establishment of an Agency Work Plan and Budget is a follow-up to the Government Work Plan (RKP) established at the time of the preparation of a draft state budget. The RKAK/L aims to obtain the maximum benefit with limited resources by taking into account the input cost standards in order to achieve efficiency. ${ }^{15}$

Another fundamental thing in the State Finance Law is the change from the Taccount format to the I- account, starting in 2000. In the T-account format, revenue is on the left, expenditure is on the right, and the principle of a balanced and dynamic budget is taken into account. While in the I-account format, revenue and expenditure are in one column so the derivation of surplus/deficits can be clearly observed. In the case of a deficit, the I-account format shows the amount of funding to cover the deficit. This I-account provides several advantages, including increasing transparency in the preparation of the APBN, facilitating the implementation of fiscal decentralization and

\footnotetext{
${ }^{13}$ The National Development Planning Agency

14 Ibid.

15 Ibid.
} 
financial balance between the central and local governments, and facilitating an international comparative analysis by using the government's financial statistics. ${ }^{16}$

\subsection{Indonesian Budget Politics}

The preparation of the APBN in Indonesia is a long process, which is both technocratic and political. The technocratic process is a process carried out by an executive agency, in this case, the Ministry of Finance, the line ministries/agencies, and Bappenas, and involves experts using valid data, and paying attention to the policies that have been set. As the government's main instrument for managing a country's economy, the APBN is also very closely linked to political decisions. ${ }^{17}$ The political process begins with the submission of the State Budget Bill and a financial memorandum, along with the details of the budget, by the president to the DPR so the enactment of a state budget law can occur, after it has been through a process of mutual discussion. Due to the function of the APBN is very vital and concerns the interests of all the people of Indonesia, the preparation is not only carried out by the executive but also requires the role of the legislative body in the form of approval of the draft budget that has been prepared by the government. ${ }^{18}$ It is in accordance with Article 23 of the 1945 Constitution, which states that: (1) The APBN, as a form of state financial management, is stipulated annually by law and carried out openly and responsibly for the greatest prosperity of the people. (2) The draft of the APBN law is submitted by the President to be discussed by the DPR, taking into consideration the opinion of the DPD. (3) If the DPR does not approve the draft state budget proposed by the President, the government will implement the previous year's state budget. Furthermore, the process of preparing, drafting, and discussing the APBN refers to the State Finance Law and MD3 Law.

Arifin P. Soeria Atmadja argues that the meaning of legislative agreement in the APBN process is a form of people's sovereignty, as stated by Rene Stourm, that "the constitutional right which a nation processes to authorize public revenues and expenditures do not originate from the fact that the members of that nation contribute the payments. This right is based on a loftier idea: the idea of sovereignty."19 In the context of transparency and avoiding abuse or excessive pressure from political parties, the budget's discussions and approval process in the DPR must be carried out openly. This is in line with the opinion of Joachim Wehner, who said that the legislative's roles in the budget are: "(1) constitutional requirements and the power of purse, (2) checks and balances as ingredients for good governance, (3) openness and transparency, (4) participation and consensusbuilding." 20

The budgeting system itself is greatly influenced by the system of government adopted by a country. In general, the system of government in the world is divided into two types: the parliamentary system and the presidential system. The parliamentary system is an older system that was first implemented in England as a substitute for an

16 Direktorat Penyusunan APBN, Op.cit, hlm. 12-13.

17 Muin, F. (2014). “Otonomi Daerah Dalam Perspektif Pembagian Urusan Pemerintah-Pemerintah Daerah dan Keuangan Daerah", Fiat Justisia Jurnal Ilmu Hukum, 8(1):..

18 Yunus, Y \& Faraby, R. (2014). "Reduksi Fungsi Anggaran DPR Dalam Kerangka Checks and Balances: Kajian Putusan Mahkamah Konstitusi Nomor 35/PUU-XI/2013", Jurnal Yudisial, 7(2):..

19 Atmadja, A. P. S. (1984). Hak Budget DPR-RI, Jurnal Hukum dan Pembangunan, 14(1):19.

20 Wehner, J. (2004). Back From Sidelines? Redefining the Contribution of Legislatures to The Budget Cycle. Jakarta: The World Bank. 
absolute system. Democracy in Britain gave great power to the people through its representatives in the Lower House (House of Commons), without removing the King's power. In a parliamentary system, the ministers are led by a prime minister and the executive and legislative bodies depend on each other. The Parliamentary Cabinet, as the responsible executive body, is expected to reflect the political forces in the legislature that support it, and the continuation of the Cabinet depends on the support of the legislature.21 A distinctive feature of the parliamentary system is that the executive power is directly under the parliament. Parliament has a dominant and active role in the governing process, while the executive is more passive. Jimly Asshiddiqie said that the government system is said to be parliamentary if: (a) The leadership system is divided into the positions of head of state and head of government as two separate positions. (b) If the governmental system is determined to be accountable to parliament. (c) The Cabinet can be dissolved if it does not have parliamentary support. (d) The government can also dissolve parliament, if it is deemed unable to support the government. ${ }^{22}$

Meanwhile, the presidential system is associated with the American system of government. In this system, the relationship between the body holding the legislative power (legislative) and the body holding the governmental authority (executive) does not exist or is free. The executive is not responsible and cannot be overthrown by the legislature, even though the policies implemented are not approved or opposed by the legislature. ${ }^{23}$ The presidential system not only places the president as the center of executive power (chief of the executive) but also the center of state power (chief of state). In a presidential system, ministers are assistants and are directly led by the president. Jimly Asshiddiqie said that the government system is said to be presidential if: (a) The position of head of state is not separated from the position of head of government. (b) The head of state is not accountable to parliament, but directly responsible to the people who elect him/her. (c) The president does not possess authorization to dissolve the parliament. (d) The Cabinet is fully accountable to the president as the holder of the state's governmental powers or as the highest administrator. ${ }^{24}$ The presidential system is characterized by the separation of powers, while the parliamentary system is characterized by a close relationship between the executive and parliament. Does the question then arise as to which type the Indonesian government system falls into? Suwoto Mulyosudarmo argues that the differentiation of the system of separation of powers from the integrated power system is based on the differentiation of the law-making process. The difference between the presidential and parliamentary systems is upon the executive's power system. In the process of making laws, Indonesia adopts an integrated power system, whereas in managing executive power it uses a presidential system. ${ }^{25}$

After the Fourth Amendment of the 1945 Constitution, Indonesia's constitutional system underwent very fundamental changes. The amendment influenced the structure of the organs of the Republic of Indonesia. It emphasized not only the

21 Budiarjo, M. (2008). Dasar-Dasar Ilmu Pilitik. Jakarta: Gramedia Pustaka Utama, p. 297.

22 Asshidiqie, J. (2006). Pengantar Ilmu Hukum Tata Negara, Jilid II. Jakarta: Konstitusi Press, p. 60.

23 Zulfan (2018). "Analisis Pengaturan dan Praktik Pemisahan Kekuasaan Sistem Pemerintahan Presidensial Berdasarkan Konstitusi". Media Hukum, 25(1):..

24 Opcit, p. 295.

25 Mulyosudarmo, S. (1997). Peralihan Kekuasaan, Kajian Teoritis dan Yuridis Terhadap Pidato Nawaksara. Jakarta: Gramedia Pustaka, p. 35. 
president's function but also the function of parliament. The legislative power which was previously dominated mainly by the President, has now shifted to become a power of the DPR. ${ }^{26}$ Legislative power became broader and intensified in many aspects, including the authority to propose laws, the authority to control the government, the authority to test and appoint leaders/members of commissions/independent bodies, and ambassadors. Article 20 A paragraph (1) of the 1945 Constitution states that the DPR has a legislative function, a budget function and a supervisory function. The DPR's budget function is also known as its budgetary right which is the right to participate in determining the budget that has been prepared and submitted by the government. The State Budget (APBN) is an authorization by the DPR for the government to undertake a certain maximum amount of expenditure or financing in the budget. ${ }^{27}$

Before the reform era, the legislature's budgetary right was from Article 23 paragraph 1 of the 1945 Constitution, which states that parliament can approve or reject a budget proposed by the government. In this concept, all forms of the state budget proposed by the government are the absolute responsibility of the government. The DPR does not have the authority to change the proposed budget. At that time, the executive position was powerful where Bappenas and the Ministry of Finance played a big part in preparing the state budget. Such conditions occurred because there were no clear limits regarding the exertion of the DPR's budgetary rights in the discussion of the draft APBN and the draft $\mathrm{APBN}$ 's revision. ${ }^{28}$

In the aftermath of reform, there was a change that was quite fundamental: the budgetary right was abolished and replaced with the budgetary function. Article 20A paragraph (1) of the 1945 Constitution confirms that the DPR has the legislative function, the budget function, and the supervisory function. Such functions are then reaffirmed in Article 69 of the MD3 Law. The budget function extends the authority of the DPR to discuss and give or not give approval to the State Budget Bill proposed by the president, as stated in Article 70 paragraph (2) of the MD3 Law. Article 23 paragraph (2) and (3) of the Amendments of 1945 Constitution state that, (1) the president is the only one authorized to submit an APBN bill, (2) the DPR is a legislative body that discusses the APBN bill with the DPD's considerations, and (3) if the DPR does not approve the bill, the government uses the previous year's state budget. With regards to the last provision, the previous year's state budget is defined as the amount of money allocated per organizational unit, function, and program, not output. Therefore, the government still can arrange new outputs and activities under the established National Medium-Term Development Plan (RPJMN) and Long-Term Development Plan (RPJP). The term "discuss the APBN bill" stated in Article 23 of the amendments to the 1945 Constitution implies that there must be a joint discussion between the government and the DPR. This mechanism places the DPR in a strong position in the discussion of the bill. In other words, the DPR has a broad authority

\footnotetext{
26 Indrayana, D. (2010). “In Search For A Democratic Constitution: Indonesia Constitutional Reform 1999-2002", Media Hukum, 17 (1):..

27 Bohari. (1995). Hukum Anggaran Negara. Jakarta: Raja Grafindo Persada, p. 15.

28 Susanto, M. (2013). Hak Budget Parlemen di Indonesia. Jakarta: Sinar Grafika, p. 1.
} 
(unrestricted power) in which the DPR can dismantle various proposals submitted by the president. ${ }^{29}$

\subsection{Revised State Budget and Its Urgency}

In the course of the stipulated state budget law, it is possible to make changes if the state is in an emergency condition or meets the requirements as stated in Article 27 of the State Finance Law, as follows:

(1) The central government prepares a report on the realization of the first semester of the APBN and the prognosis for the next six months.

(2) The report referred to in paragraph (1) shall be submitted to the DPR not later than the end of July of the fiscal year concerned, to be discussed together by the DPR and the central government.

(3) Adjustments to the APBN with developments and/or changes in circumstances are discussed by the DPR and the central government in the context of preparing forecasts for changes to the APBN in the relevant fiscal year if the following circumstances take place:

a. Macro-economic development that is not in accordance with the assumptions used in the APBN.

b. Changes in the main points of the fiscal policy.

c. Circumstances that cause the budget to be shifted between organizational units, between activities, and between types of expenditure.

d. Circumstances that cause the surplus balance from the previous year to be used to finance the current budget.

(4) In an emergency, the government can carry out unbudgeted expenditures, which are subsequently proposed in a bill for the revision of the state budget and/or accounted for in the budget's realization report.

(5) The central government shall submit a bill for the revision of the state budget for the relevant fiscal year, based on the changes referred to in paragraph (3), to obtain approval from the DPR before the relevant fiscal year ends.

The criteria for the urgency of the revision of the state budget are sharpened in Article 183 of the MD3 Law. The MD3 Law allows a certain percentage of changes to the macro-economic assumptions and changes to the budget's posture, as follows:

(1) In the event of a significant shift in the macro-economic assumptions and or to the state budget's posture, the government shall submit a bill of revision to the state budget for the current fiscal year.

(2) The significant changes to the macro-economic assumptions referred to in paragraph (1) are:

a. a decline in the economic growth of at least one percent below the initial setting; and/or

29 Mei Susanto. (2016). Hak Budget DPR Dalam Pengelolaan Keuangan Negara (Budget Right in State Finance Management), Jurnal Rechtvinding BPHN, 5(2): 
b. a deviation of other macro-economic assumptions of at least ten percent of the initial setting.

(3) The significant changes to the APBN's posture, as referred to in paragraph (1), are:

a. A decrease in tax revenue of at least ten percent of the stipulated ceiling.

b. An increase or decrease in line ministries/agencies expenditure of at least ten percent of the stipulated ceiling.

c. The emergence of urgent expenditure which is unbudgeted.

d. An increase in the deficit of at least ten percent of the initial deficit to GDP ratio.

(4) The discussion and determination of the bill for the revision of the state budget, as referred to in paragraph (1), shall be carried out by the government together with the budget board and related commissions of the DPR within a maximum period of one month during the session after the government submit the bill for the revision of the state budget to parliament.

(5) In the event that there are no significant changes to the macro-economic assumptions and/or the APBN's posture, as referred to in paragraph (2) and paragraph (3), the discussion of the revision to the state budget shall be conducted in a meeting of the budget board of the DPR and the implementation thereof shall be accounted for in the government's financial report.

The law concerning the state budget has a general, concrete nature and is different from other laws that are abstract. The general nature of the state budget means that it regulates the public interest in accordance with the greatest prosperity of the people. It is not abstract since it governs concrete, precise, specific actions that must be carried out by the government within a particular amount of time (one year). Since each state budget law is only valid for one year, the proposed amendment to the bill must finish before the fiscal year ends. It cannot be done in the following fiscal year. ${ }^{30}$

Article 27 of the State Finance Law regulates changes in the state budget, but it still leads to multiple interpretations. Article 27 of the State Finance Law, as a single article, can be interpreted that any revision of the state budget is part of the First Semester State Budget Realization Report, and is submitted by the government to the DPR before the fiscal year ends. If the First Semester State Budget Realization Report is submitted after June, changes to the state budget can be made somewhere between July and December. In practice this is quite difficult since if a revision to the state budget is submitted after June, and followed by discussion sessions with the DPR, then the adjustments to the Budget Implementation Entry List (DIPA) have to be completed in a minimal time (until the end of the fiscal year). This situation creates difficulties for line ministries/agencies since they do not have enough time to complete their activities, especially for the activities related to capital expenditure. The discussion of the revision to the state budget by the DPR is time-consuming, since the discussions not only focus on what has changed, but also on the whole of the budget, whether or not all of it has been revised.

If Article 27 of the State Finance Law is interpreted not as a single article, then it implies that the revision of the state budget is not part of the First Semester State

30 Susanto, S. (2017). “Kewenangan Mahkamah Konstitusi Sebagai Negative Budgeter Dalam Pengujian Undang-Undang Anggaran Pendapatan dan Belanja Negara", Jurnal Mahkamah Konstitusi, 14(4):. 
Budget Realization Report. When the criteria to revise the state budget, as stipulated in the State Finance Law and MD3 Law are fulfilled before June, then the revision of the state budget can be proposed to and approved by the DPR before fiscal year ends. However, this interpretation creates another question about which documents can be used as the basis to prove whether or not the criteria, as referred to in Article 27 of the State Finance Law and the MD3 Law, are met.

Between 2008 and 2017, there were several revisions to the state budgets that were submitted and stipulated before June which were amendments to 2008, 2010, 2011, 2012, 2013, 2014, and 2015 state budgets. It means that the government's proposed changes to the budgets were made before the First Semester State Budget Realization Reports. These earlier submissions were aimed to ensure the soundness of the implementation of the current year's state budget by adjusting the amount of state revenue, state expenditure, budget deficits, and budget financing to more realistic levels that allow the achievement of specified development targets. By proposing the revisions earlier, the government had sufficient time to adjust its activities, especially those related to capital expenditure, which involves a complicated procurement process.

The criteria for the APBN's amendment, as stipulated in the MD3 Law, seem to bind the government to always submitting state budget revisions every year. Since 1970, the government has proposed a change to the state budget every year. In the 1998/1999 and 2005 fiscal years, the alterations occurred twice a year. In 2018, due to the fluctuations in the global economy, the exchange rate underwent a relatively high deviation of IDR 14,247 per US\$ from the initial assumption of IDR 13,400 per US\$. Likewise, oil prices exceeded the assumptions set at US \$ 67.5 per barrel from the initial assumptions of US \$ 48 per barrel. With the development of a highly fluctuating global economy, it was very likely that the government would adjust the macroeconomic assumptions that had been set previously. The phrase "in terms of" in Article 183 of the MD3 Law implies that such conditions can occur at any time of the year. Article 183 of the MD3 Law uses the conjunctions "and/or" so that if one of the conditions in paragraph (2) or (3) is fulfilled, the government must submit a Bill of Revision of the State Budget for the current fiscal year to be discussed by the DPR. There is a concern that in the discussion process with the DPR there is a transactional agenda that is difficult to avoid. The arrest of some of the members of the DPR, employees of the Ministry of Finance, and private parties by the Corruption Eradication Commission (KPK) related to the Regional Financial Balance Fund scandal with the amendment to the APBN in 2018 is proof that there is a high likelihood of the occurrence of transactional activities during the discussion of the revision to a state budget by the DPR. The scandal still took place even though the revision of the state budget was finally not proposed by the government, since the economic circumstances were then considered to be under control. The government's decision not to revise the 2018 State Budget was right since the 2018 budget's performance was then excellent.

Based on the above description and the statement of the 1945 Constitution, it can be clearly stated that Indonesia employs a presidential government system. Therefore, the authority to submit a bill for the state budget and its revision solely lies in the president's hand. It means that the president bears all risks that may arise. Thus, the government's decision not to propose a revision to the state budget in the event that the criteria to revise the state budget, as stipulated in the State Finance Law and the 
MD3 Law are fulfilled, theoretically is not a violation of the current laws and regulations.

\section{Conclusion}

According to the presidential system, the authority to submit a bill for the state budget and its revision lies solely in the president's hand. It means that the president bears all the risks that may arise. Thus, the government's decision not to propose a revision of the state budget if the criteria to revise it, as stipulated in the State Finance Law and MD3 Law are fulfilled, theoretically is not a violation of the current laws and regulations.

The choice to submit or not submit a revision of the state budget, after going through careful consideration by the government, is aimed at maintaining its credibility since the existence of a revision implies that the government is unable to undertake precise budget planning, while the occurrence of transactional agenda in the discussion of such a revision is very likely, along with other considerations.

It should be noted that if the government decides to submit a revision to the state budget, the government needs to consider the philosophy of the state budget's objectives, to achieve the country's goals. So, the sooner a bill for the revision of the state budget is proposed, and approved by the DPR, the more time the line ministries/agencies have to execute the revised budget.

\section{References}

Books:

Asshidiqie, J. (2006). Pengantar Ilmu Hukum Tata Negara, Jilid II. Jakarta: Konstitusi Press.

(2003). Struktur Ketatanegaraan Indonesia Setelah Perubahan Keempat UUD 1945, Denpasar: BPHN, Departemen Kehakiman dan Hak Asasi Manusia.

Bohari. (1995). Hukum Anggaran Negara. Jakarta: Raja Grafindo Persada.

Budiarjo, M. (2008). Dasar-Dasar Ilmu Politik. Jakarta: Gramedia Pustaka Utama.

Direktorat Penyusunan APBN, Ditjen Anggaran, Kementerian Keuangan Republik Indonesia. (2014). Dasar-Dasar Praktek Penyusunan APBN di Indonesia. Jakarta: Direktorat Penyusunan APBN, Ditjen Anggaran, Kementerian Keuangan Republik Indonesia.

Kementerian Keuangan Republik Indonesia. (2016). Nota keuangan dan Undang-Undang Republik Indonesia nomor 36 tahun 2004 tentang Anggaran Pendapatan dan Belanja Negara Tahun Anggaran 2016. Jakarta: Kementerian Keuangan Republik Indonesia.

Marzuki, P.M. (2005). Penelitian Hukum. Jakarta: Kencana Prenada Media Group.

Suwoto, M. (1997). Peralihan Kekuasaan, Kajian Teoritis dan Yuridis terhadap Pidato Nawaksara. Jakarta: Gramedia Pustaka. 
Simatupang, D.P.N. (2011). Paradoks Rasionalitas Perluasan Ruang Lingkup Keuangan Negara dan Implikasinya terhadap Kinerja Keuangan Pemerintah. Jakarta: Badan Penerbit FH UI.

Atmadja, A.P.S. (1986). Mekanisme Pertanggungjawaban Keuangan Negara, Suatu Tinjauan Yuridis. Jakarta: PT. Gramedia.

Sutedi, A. (2010). Hukum Keuangan Negara. Jakarta: Sinar Grafika.

Susanto, M. (2013). Hak Budget Parlemen di Indonesia. Jakarta: Sinar Grafika.

Wehner, J. (2004). Back From Sidelines? Redefining the Contribution of Legislatures to The Budget Cycle. Jakarta: The World Bank.

\section{Journal articles:}

Atmadja, A.P.S. (1978). “Sifat Hukum dari Undang-Undang Anggaran Pendapatan dan Belanja Negara". Jurnal Hukum dan Pembangunan, 8(3): .

Atmadja, A.P.S. (1984). “Hak Budget DPR-RI”. Jurnal Hukum dan Pembangunan, 14(1): .

Indrayana, D. (2010). "In Search For A Democratic Constitution: Indonesia Constitutional Reform 1999-2002". Media Hukum, 17(1): .

Muin, F .(2014). “Otonomi Daerah dalam Perspektif Pembagian Urusan PemerintahPemerintah Daerah dan Keuangan Daerah". Fiat Justisia Jurnal Ilmu Hukum, 8(1): .

Susanto, M. (2016). “Hak Budget DPR Dalam Pengelolaan Keuangan Negara (Budget Right in State Finance Management)". Jurnal Rechtvinding BPHN, 5(2): .

(2017). “Kewenangan Mahkamah Konstitusi Sebagai Negative Budgeter dalam Pengujian Undang-Undang Anggaran Pendapatan dan Belanja Negara". Jurnal Mahkamah Konstitusi, 14(4): .

Yunus, Y \& Faraby, R. (2014). “Reduksi Fungsi Anggaran DPR Dalam Kerangka Checks and Balances: Kajian Putusan Mahkamah Konstitusi Nomor 35/PUUXI/2013". Jurnal Yudisial, 7(2): .

Zulfan (2018). “Analisis Pengaturan dan Praktik Pemisahan Kekuasaan Sistem Pemerintahan Presidensial Berdasarkan Konstitusi". Media Hukum, 25(1): .

\section{Internet}

Marta, M.F. (2016), “APBN Perubahan atau APBN Pengurangan?" Kompas.com,https://money.kompas.com/read/2016/06/03/081844826/strateg i.anggaran.jokowi.apbn.perubahan.atau.apbn.pengurangan.?page=all, Accessed: September 3, 2019. 